\title{
Secular Female Imagery in Orissan Temple Architecture: the Case of Alasa Kanyas
}

\author{
Surabhi Sharman \\ Independent Researcher. Email: sharmansurabhi@yahoo.com
}

\begin{abstract}
The temple architecture from the Indian subcontinent follows a certain protocol, and the sculptural programme of the temples is in conjunction with the prescribed norms. The paper looks at the regional temple architecture of Orissa, specifically at the profusion of secular female imagery, in the form of alasa kanyas or 'indolent maidens' that adorn the Orissan temples. The imagery of these maidens has been discussed in the Orissan text on temple architecture, Shilpa Prakasha of Ramachandra Mahapatra Kaula Bhattaraka from c. $11^{\text {th }}$ century CE, and is the primary source of contemporary information on the subject.
\end{abstract}

Keywords: Orissan Temple Architecture, Temple Sculptures, Female Sculptures, Alasa Kanya, Orissa

The Orissan temples are replete with motifs of beautiful women posed shown engaged in playful activities, in graceful poses. Such figures of women are not exclusive to Orissa, but the Orissan temples are profusely carved with this imagery. The concern of this research is specific to the female imagery that is of secular nature, focussing on the images of alasa kanyas, on the decorative and iconographical programme of temples in Orissa.

Medieval temple walls are adorned with images of beautiful women in various mesmerising and erotic poses. These images of women are seen to pay homage to the Devi, and her various aspects. There is a variety of female imagery depicted in the decorative and iconographic programme of the temple. The different types of females that are depicted on temple walls include divine, semi-divine and secular. The divine images are meant for worship and include images of goddesses as both standalone deities and as consorts of the different forms of the Hindu Holy Trinity - Brahma, Vishnu and Mahesh (Shiva). Then, there are images of apsaras, sursundaris, nagis, alasa kanyas, and so on. These are different types of females, each with different aspects that are found in art and literature. The alasa kanyas are popularly known as nayikas in other parts of the country and in Sanskrit literature, which brims with poems and stories extolling the beauty of the nayikas.

The Shakta cult in Orissa influenced the imagery on the decorative programme of the temple and the profusion of such imagery on temple walls can also be linked directly to the evolution of temple architecture. The $10^{\text {th }}$ century saw the pancha-ratha plan of temple being developed and adopted as a standard plan for temple building. The pancha-ratha plan offered many niches for the sculptures. The corner niches or the kanika pagas began to be dominated by the imagery of alasa kanyas. In many cases, these beautiful damsels started to replace mainstream gods and goddesses as decoration in the pagas or niches. ${ }^{i}$ The evolution of the temple wall into a double storey jangha in the temple architecture of the period led to the images of alasa kanyas being sculpted on the top storey as well. These beautiful damsels because of their position above the eye level, began to resemble a celestial maiden, looking below from the heavens above. ${ }^{\text {ii }}$ 
The imagery of these alasa kanyas is often charged with eroticism in their conception. The beautiful maidens seem to be enchanting men to them with their playful glances and curved postures. Many of them are seen engaged in the scene of toilette. One wonders, what are these images doing on temple walls? The Shilpa Prakasha, a medieval Orissan text on temple architecture, explains the presence of these images together in a row known as the Nari Bandha.

"By the people it is called Nari bandha (row of female figures) arising from art. As a house without a wife, as playful enjoyment without a woman. (I.392)

So without (the figure of) women art will be deficient and bear no fruit. Gandharvas, Yakshas, Rakshasas, Pannagas (nagas) and Kinnaras, (I. 393)

become enchanted on seeing the graceful postures of women. Woman is most beautiful, when adorned with all ornaments. (I.394)

Displaying various postures, she is known as Alasa, and is decorating the gavaksha, the shikhara, the walls and other parts of the mukhasla. (I.395)

The Shilpa Prakasha illustrates the presence of at least sixteen types of alasa kanyas which can be found on the temple walls of Orissa. These damsels find mention directly and indirectly in various sources of Sanskrit literature. The conception of the alasa kanya is based on the Alasa Yantra or a magical diagram that specifies the lines on which different postures are executed. ${ }^{v}$

The Shilpa Prakasha illustrates sixteen types of maidens who are conceived on the Alasa Yantra. These sixteen maidens are Torana (one forming an arch), Mugdha (the innocent), Manini (the offended), Dalamalika (holding a branch like a garland), Padmagandha (smelling the lotus), Darpana (holding a mirror), Vinyasa (the well-groomed), Ketakibharana (one wearing ketaki blossom), Matrmurti (the mother), Chamara (one holding a fly whisk), Gunthana (the one who hides herself), Nartaki (dancer), Shukasarika (One playing with a parrot), Nupurpadika (one wearing anklets) and Mardala (drummer). Each of the alasa kanya is discussed in detail below.

\section{Torana (Forming an arch)}

The first kind of alasa kanya is torana, who like her name suggests forms an arch by joining her two hands above her head. The Shilpa Prakasha also mentions that her palms are spandita (turned downwards). The Shilpa Praksha defines two types of movements of hands, the chhandita (palm turned upwards), and spandita (palm turned downwards) for all the alasa kanyas. ${ }^{\mathrm{vi}}$

The ancestry of the torana can be linked to a stylised form of the salabhanjika known as toranasalabhanjika. Most commonly seen on the toranas or gateways of the Stupa at Sanchi, these figures hold a single arm up to slightly bend the branch of a tree. In Sanskrit literature, we come to the reference of the toranasalabhanjika in one of Ashvaghosha's verse where he compares the resemblance between the toranasalabhanjika and women who are watching Siddhartha leaning from their windows. The verse reads,

"Another damsel, holding to the side of a window and with her body flexed beautifully like a bow and with her pearl necklace dangling, looked like a carved decorative figure on the torana gateway."vii viii

The image of the torana from the palm leaf manuscript of Shilpa Prakasha, shows the torana in the likeness of the text with both arms joined together on top is found at the Rajarani Temple, Bhubaneshwar. The image on the architectural torana or gateway at the Muktesvara Temple in Bhubaneshwar can be identified as a form of the torana. On the top of the gateway, 
two alasa kanyas are shown on either side of semi-circle top with one arm held from either side towards each other, thus forming an arch.

\section{Mughda (Innocent and simple girl)}

The second type of alasa kanya to be described in the Shilpa Prakasha is Mugdha. She is pronounced as the one wearing beautiful ornaments, with her right arm in a naga mudra (like a snake hood) and her left hand is shown to be on her hip. ${ }^{\text {ix }}$

\section{Manini (Resentful or offended girl)}

The third type of alasa kanya to be described in the Shilpa Prakasha is Manini. She is ornamented with a beautiful coiffure, her body covered in draperies and her breasts covered with a breast band (stana pata). Her left hand is shown touching her lower lip and her other hand is held over her head which is understood as a sign of pride. The author describes her beautiful face with half opened eyes and her mouth slightly open. The lower lip expresses love or lasya bhava. ${ }^{x}$

In literature, the offended girl is shown to be angry with her lover in various stories. Such an aspect is known as anunaya where the angry woman is being cajoled by her lover to forgive his discretions. In the Raghuvamsa of Kalidasa, a bird speaks to the offended lady to shed her anger in the verse,

"Shed your false dignity and anger; enough with your quarrels; youth gone never returns."xi

\section{Dalamalika (Holding a branch like a garland)}

This alasa kanya is described by Bhattaraka as holding along branch with her right hand as her left arm touches the other end of the branch. The whole figure is supposed to be conceived at a right angle on the alasa yantra. ${ }^{\text {xi }}$

The ancestry of the dalamalika can be traced to the ashoka dohada ritual. Coomaraswamy conjectures that the woman and tree motif developed into three distinct forms. One of these forms was the ashoka dohada. In Sanskrit literature, ashoka dohada is a ritual wherein it is believed that the Ashoka tree will only blossom when it is touched by the feet of a beautiful maiden. The touch of a beautiful woman brings the tree to a full blossom. This is yet another example that connects female figures to the cult of fertility and auspiciousness. In literature, this ceremony is seen in Kalidasa's third act of Malavikagnimitra,

"When palace maid Samahitika visits the pleasure garden of the king she finds the golden Ashoka tree without flowers. The matter is reported to the chief queen Dharini. As her foot is injured due to fall from the swing, she entrusts the task of ashoka dohada to her beautiful palace attendant, Malavika, with the promise to give her any reward she would ask, if Ashoka starts blooming within five days....Bakulvalika (her friend) paints the feet of beautiful Malavika with red dye and puts on anklets to make her ready for the dohada ritual........Malavika then plucks the colourful leaves of Ashoka and places their bunch on her ears. Now ready for the ritual - feet coloured with red dye and made musical by the tinkling ankle bells and wearing ear rings of Ashoka leaves - she hits the tree with her feet." ${ }^{\text {iii }}$

Another evidence of the woman and tree motif is seen in the Mahabharata (Vanaparva), Chapter 265, where Draupadi stands clutching the branch of a Kadamba tree. Kotikasya, a friend of King Jayadratha (who saw her standing alone under the tree) is sent to enquire. He enquires: "Who art thou clasping the branch of Kadamba tree, slightly bent by the breeze shining all alone in hermitage, glittering like a flame of fire in the night." xiv 
The dohada ritual in early sculptural art of India portrayed the damsel in the movement of kicking the tree. In later sculpture, especially in Orissan sculpture the depiction contained itself to a beautiful damsel touching or holding a branch of a tree. The idea behind the depiction remained the same though. The dalamalika sculptures of Orissa are representative of the same idea of fertility cults. Vallabhadeva's verse from Subhashitavali illustrates the dohada ritual,

"Having gathered first the collection of flowers within her reach, the fawn eyed damsel, desirous of holding to the branch, laid her foot on the bare bough of the Ashoka tree and again from the root it put forth flowers." ${ }^{\mathrm{xv}}$ xvi

\section{Padmagandha (Smelling the lotus)}

The next alasa kanya described in the Shilpa Prakasha is padmagandha. She is described as the ever-beautiful maiden whose stance is bent towards the left. She is shown holding a lotus in her left hand whereas her right arm rests on her hip. She is christened padmagandha because she finds the fragrance of lotuses pleasing. ${ }^{\text {xvii }}$

\section{Darpana (Holding a mirror)}

The next damsel described in the Shilpa Prakasha is Darpana. As the name describes, she is the maiden who holds the mirror. Looking at herself, holding the mirror in front of her face, she is pleasing to the viewer. Her beautiful looks are accentuated by her coiffure which places her hair towards the front. Her lower portion is covered in beautiful draperies. Bhattaraka states that mirror could be placed in any way as per the artist's choice. ${ }^{\text {xvii }}$ She is one of the most widely depicted alasa kanyas in Indian sculpture. Images of darpana are found in Khajuraho and in other temples, such as in Belur as well.

\section{Vinyasa (Well-groomed)}

The Shilpa Prakasha illustrates another type of maiden which is vinyasa. She is pronounced as standing in profile, with beautiful limbs. Her hand is in the karakacchapika mudra, that is the gesture of the shape of a tortoise. The other hand is in the gesture of the japa nyasa which is the act of repeating the names of God. Her face is shown to have a meditative look. ${ }^{\text {xix } x x}$

\section{Ketakibharana (Wearing Ketaki blossom)}

Ketakibharana is the eighth alasa kanya to be described in the Shilpa Prakasha. She is seen as an auspicious figure who in her left hand holds ketaki flowers. She has heavy hips and her right leg is shown crossed behind her left leg. ${ }^{\text {xi }}$

\section{Matrmurti (Image of a mother)}

The ninth alasa kanya that is described in the Shilpa Prakasha is a true testament to the fertility cult from which all of these images are derived. The matrumurti is the image of a mother. In her left arm she is shown holding a child while her right-hand rests on the thigh. This is essentially an image of a mother and child. ${ }^{\text {xii xxiii }}$

The mother and child motif can be traced back to the Indus Valley Civilisation. In the period between 2700-1500 BCE, when the Indus Valley Civilisation flourished, figures of the female form were produced abundantly. These female figures were at times depicted as pregnant, or with children, with overly emphasised breasts. These figures formed a major part of the fertility cult that survived and flourished in different forms in the centuries ahead. These figures were also shown as heavily ornamented. ${ }^{x i v}$ From the Indus Valley to the medieval period, the tender relationship of mother and child remained an important image and continued to be produced in 
5 | Secular Female Imagery in Orissan Temple Architecture: the Case of Alasa Kanyas

art. From the divine images of the family of Shiva to the more secular ones such as those carved on the temples of Orissa, an unbroken continuity of the image can be traced.

\section{Camara (Holding a flywhisk)}

The next alasa kanya is described as an attendant of the deities of the temple. She is shown in a similar stance as the matramurti and the only difference is instead of a child, she holds a fly whisk in one hand and the other hand is shown in the gesture of gathering her lower drapery. The fly whisk rests on her left shoulder and she is known to bring joy to her deities. ${ }^{\mathrm{xxv}}$

\section{Gunthana (Hiding herself)}

The next alasa kanya is gunthana, who is shown from the backside. Her one hand is shown to cover any visible trace of her face. She stands erect in the virasana, i.e. with a virile attitude. She is also called mahavidya and may carry a fan or flowers in her hand. ${ }^{\text {xxi }}$

\section{Nartaki (Dancer)}

The next type of alasa kanya discussed in the Shilpa Prakasha is the dancer. Her leg is shown crossed behind the other and she is shown in the movement of dance. She is described to be looking like a celestial damsel as she is lost in her dance.

The subject of dance has been carefully explored by the Indian sculptor since the ancient times. The earliest image of a woman in dancing pose is found from the Indus Valley Civilisation. The image of the Dancing Girl evolved eventually into a more complex image which began to portray the technical details of the various dance forms. The different dispositions of hands, legs and feet are called sthanas or karanas. Each disposition is prescribed with a specific meaning. In Sanskrit literature, different aspects of dance are explored and written about in detail in various texts such as the Natyshastra of Bharata which expresses the various karanas or hand movements of a dancer. A beautiful verse from Kalidasa's Malvikagnimitra perfectly captures in poetry the beauty of a dancer, which can also be suitably applied to sculptures of the subject.

"Eyes long, face beautiful like the autumnal moon, arms drooping, shoulders narrow, breasts close and elevated, the sides appearing kneaded, the waist just the measure of the palm, the hips huge, feet with bent toes, the body of this damsel is fashioned just as a dancer could wish it to be." xxviixxviii

Vatsyayan describes the dance sculptures on the temples of Orissa to be representative of the caris (dance steps) that are defined in the Natyashastra of Bharata. The walls of the natamandira (dance hall) at the Konark temple as discussed before is dotted with imagery of dance. ${ }^{\text {xix }}$

Nadikeshvara, the dramaturgist who penned Abhinayadarpana explains the female dancer in her ideal state and describes that she should be:

"Slender (tanvi), beautiful (rupavati), or swarthy complexion (shyama - also means girl who has marks of puberty, woman who has born no children or female of slender shape), having swollen, rounded, full corpulent breasts somewhat turned upward (pinonnata payodhara), bold, proud and confident (pragalbha), juicy, having fluid movements, capable of emoting sentiments or rasas (sa-rasa), lovely (kanta), skilled (kushala), having large eyes (vishal-lochana), face pleasing like lotus in full bloom (Prasanna-mukhapankaja), well dressed and capable of following song, music and rhythm (gita-vadyatalanuvartini)." 
6 | The Chitrolekha Journal, Vol. 4, No. 2, 2020

\section{Shukasarika (Playing with a parrot or a maina)}

The shukasarika is the maiden who is shown adorned with a parrot as the name suggests. The parrot could be replaced at times with a maina as well, who are shown to be perched on her hand. Her other arm is positioned just before her breast.

\section{Nupurpadika (With ankle bells)}

The nupurpadika is that maiden who is shown holding a lotus bud in her right hand. She is shown with a beautiful body, her knees slightly bent. She is bent in a position with her left hand on her ankle bells as if putting them on or taking them off. ${ }^{\text {xxxi }}$

The nupurpadika can be seen as a type of vassaksajjika nayika i.e. the one who decks herself in ornaments and carefully attends to her looks as she waits for her lover to come. In Sanskrit literature, a very similar scene of taking off or putting on anklets hurriedly is described.

"Vita - But oh timid lady, the smell from garlands and the resounding ankles will betray you. Do you hear Vasantasena?

Vasantasena (within herself) - I have heard and acted accordingly. (By gesticulation she removes the anklets and puts aside the garlands, moves aside and touches with her fingers."xxxii

\section{Mardala (Drummer)}

The last and the sixteenth alasa kanya to be mentioned in Shilpa Prakasha is mardala. She is the only musician included in the group of alasa kanyas, although there are many images that show women playing a variety of instruments, especially at the temple of Konark. Her head is shown slightly tilted and her facial features express her to be lost in her playing. There is a drum in front of her, which she is shown to be playing. ${ }^{\text {xxiii }}$

The prescribed depiction of the sixteen types of alasa kanyas by Bhattaraka in the Shilpa Prakasha, finds a practical manifestation on the temple walls of Orissa. Dotted with hundreds of temples, that were being built from c. $7^{\text {th }}$ century onwards, Orissa was a cradle of Tantrism as well. With strong roots in tantra and the popularity of Shakta cults, the profusion of female imagery, both sacred and secular in nature is hardly surprising. The classification of maidens as secular or semi-divine, is a subject of contention, and it is especially hard to differentiate between the varied the nature of imagery, because the temples are so richly carved. The Orissan temple sculpture programme developed its own style, which was rooted in tradition, but is specifically regional in nature, and the depiction of alasa kanyas is specifically characteristic of the region's temple architecture.

\section{References}

Donaldson, T. (1987). Kamadeva's Pleasure Garden: Orissa. Delhi: B.R. Publishing Corporation.

Sivaramamurti, C. (1970). Sanskrit Literature and Art - Mirrors of Indian Culture. New Delhi: Lakshmi Book Store.

Bhattaraka, R. M. (2005). Silpa Prakasa. (B. Baumer, R. P. Das, S. Das, Eds., A. Boner, \& S. R. Sharma, Trans.) New Delhi: Indra Gandhi National Centre for the Arts ; Motilal Banarsidass Publishers Pvt. Ltd.

Varadpande, M. (2006). Woman in Indian Sculpture. New Delhi: Abhinav Publications . 
7 | Secular Female Imagery in Orissan Temple Architecture: the Case of Alasa Kanyas

Vatsyayan, D. K. (1968). Classic Indian Dance in Literature and the Arts. New Delhi: Sangeet Natak Akademi.

\section{Notes}

i (Donaldson T. , Kamadeva's Pleasure Garden: Orissa, 1987, pp. 343-344)

ii (Donaldson T. , Kamadeva's Pleasure Garden: Orissa, 1987, pp. 343-344)

iii (Donaldson T. , Kamadeva's Pleasure Garden: Orissa, 1987, pp. 343-344)

${ }^{\text {iv }}$ From Shilpa Prakasha Part I

लौकिके कथितो नारीबन्धः शिल्पसमुद्धवः।

विना नारीं यथा वासः विना नारीं यथा क्रीडा॥ ३९२

विना ललनां हीनं च जायते शिल्पं निष्फलम्।

गन्धर्वयक्षरक्षांसि पन्नगाः किन्नरास्तथा॥ ३९३

दर्शनात् तत्र मुहयन्ति नागरीभड्गिमुत्तमाम्।

उत्तमा रमणी श्रेष्ठा सर्वालंकारभूषिता॥ ३९४

नानाभड्गीसमाहरे अलसा सा विधीयते।

गवाक्षे शिखरे वापि मुखशालाइ्गमण्डने॥ ३९५

v (Donaldson T. , Kamadeva's Pleasure Garden: Orissa, 1987, pp. 343-344)

vi (Donaldson T. , Kamadeva's Pleasure Garden: Orissa, 1987, pp. 343-344)

vii (Sivaramamurti, 1970, p. 1)

viii From Buddhacharita, V. 52

श्वलम्बय गवाक्षपाशर्वमन्या शयिला चापविभुग्नात्रयष्टिः।

विरराज विलम्बिचारुहारा रचिता तोरणशालभग्जिका॥

ix (Bhattaraka, 2005, p. 155)

x (Bhattaraka, 2005, p. 157)

xi (Sivaramamurti, 1970, p. 17)

xii (Bhattaraka, 2005, p. 157)

xiii (Varadpande, 2006, p. 24)

xiv (Varadpande, 2006, pp. 28-29)

${ }^{x v}$ (Sivaramamurti, 1970, p. 39)

${ }^{\text {xvi }}$ From Subhashitavali of Vallabhadeva

उच्चित्य प्रथमवस्तिथतं मृगाक्षी

पुष्पौघं श्रितविटपं गृहीतुकामा। 
ग्रारोढुं चरणमदादशोकयष्टे

रामूलं पुनरपि तेन पुपितासो॥

xvii (Bhattaraka, 2005, pp. 158-159)

xviii (Bhattaraka, 2005, p. 159)

xix (Bhattaraka, 2005, pp. 160-161)

${ }^{\mathrm{xx}}$ From Shilpa Prakasha Part I

विन्यासा

वामङ्गी दक्षिणे भङ्गी पार्वर्वमुखसुशोभना।

मस्तकप्रांतबाहुभ्यां स्कन्धदेशातिशोभनः ॥४३४

वामबाहुस्तथा वामत्रिभुजे बाहुसन्निधौ।

मध्यरेखोर्ध्वे छन्दश्च भुजदण्डश्च सम्मुखे॥ ४३५

अपरबाहुस्तद्रुपे पल्लिन्यासः स उत्तमः।

मध्यबिन्दुं समारभ्य वामपादश्च दण्डवत्त ४३६६

तद्बिन्दुः पार्ववदेशेन दक्षिणत्रिभुजावधि।

दक्षिणजानु तन्निम्ने दण्डप्रान्तवधिस्तथा॥ ४३७

जपन्याससमा मुद्रा विन्यासा ध्यानरूपिणी।

दिव्यवसनसंयुक्त्ता कटिदेशे सुशोभना॥ ४३८

This woman of beautiful limbs is turned to the right and her lovely face is seen in profile. The head is on the upper lines and she has beautiful shoulders. (I. 434)

The left arm is along the left side of the triangle. The forearm is crossing in front along the horizontal middle line. (I.435)

The other arm has the same form and the disposition of the palm is beautiful. The left leg, starting from the centre point is straight like a rod. (I.436)

From the side of that point, the right thigh goes down along the right triangle and the shin goes down the end. (I.437)

With hands in the gesture of doing japa-nyasa (repeating the names of god). Vinyasa is lost in meditation. With lovely garments on her hip, she is the most beautiful. (I.438)

xxi (Bhattaraka, 2005, pp. 161-162)

xxii (Bhattaraka, 2005, p. 163)

xxiii From Shilpa Prakasha Part I

मातृमूर्तिः

शृणु अनन्तरं दिव्यं मातृमूर्तेश्च निर्णयम्॥ ४४५

यथास्थाने स्थितं शीर्ष मध्यरेखासमन्वितम्।

समस्तशरीरं दिव्यं शृणु देहङ्गनिर्णयम्॥ ४४६

वामबाहुश्च वक्षसि वामत्रिभुजसन्निधौ। 
आरभ्य मध्यरेखान्ते तदन्ते च भुजादण्डौ॥ ४४७

तन्मध्ये बालकमूर्तिः वामत्रिकोणसन्निधौ।

मुखमारभ्य पादान्तः मध्यरेखासमाश्रितः ४४८

दक्षिणस्कन्धमारभ्य जानुदेशान्तरस्थिते।

दक्षिकरविन्यासः साधारणपदद्वयम्॥ ४४९

एषा मातृसमा मूर्तिः बालकादिविशोभिता।

Hereafter listen to the description of the beautiful mother image. (I.445)

The head is placed upon the middle line, and so is the whole beautiful body. Hear the description of the limbs. (I.446)

The left arm is along the breast, near the left triangle. Starting from the middle line to the forearms lie on the (horizontal) middle line. (I.447)

In (her arms) is the figure of a child near the left triangle. From face to foot it is on the middle line. (I.448) Hanging from the right shoulder, the right hand is placed on the thigh. Both feet are placed in a natural way. (I.449)

This image is in the beautiful likeness of a mother with a child.

xxiv (Varadpande, 2006, pp. 5-20)

xxv (Bhattaraka, 2005, pp. 164-165)

xxvi (Bhattaraka, 2005, p. 165)

xxvii (Sivaramamurti, 1970, p. 75)

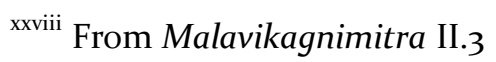

दीर्घाक्षं शरदिन्दुकान्ति वदनं बाहु नतावंसयो:

संक्षिपतं निबिडोन्नतस्तनमुरः पार्श्वे प्रमृष्टे इव।

मध्यः पाणिमितोऽमितन्च जघनं पादावरलाङ्गुली

छन्दो नर्तयितुर्थेव मनसि शिलष्टं तथास्या वपु॥

xxix (Vatsyayan, 1968, p. 320)

xxx (Varadpande, 2006, p. 74)

${ }^{\mathrm{xxxi}}$ From Shilpa Prakasha Part I

नूपुरपादिका

दक्षिणाग्डी सदा रम्या मध्यरेखान्तरस्थिता।

वामत्रिभुजरेखायां वामकरः विलम्बितः॥४६१

पूर्ववद् दक्षिणकरे कलिकावरधारिणी।

अधोदेशे द्वयोर्मध्ये दक्षिणः कुस्चितस्तथा॥४७०

दक्षजानु तथा निम्ने प्रथमप्रस्थस्पर्शिनी।

पाददण्ड तथा न्यसेत् तिर्यड् च वामपाश्रवके॥४७१

वामकरं यथा न्यसेत् तथा नुपुरमालिका। 
वाम्क्रिघ्रल्बि्बितो निम्ने मध्यरेखांतवर्त्तिनी॥४७२

The beautiful body, standing along the vertical middle line is turned towards the right. The left arm hangs down on the line of the left triangle. (I.469)

In her right hand, as described before (in the previous category), she holds a beautiful flower bud. In the lower part, of the two legs the right one is bent. (I.470)

The right knee below touches the first horizontal. The position of the shank is obliquely set towards the left side. (I.471)

The left hand is placed where there is a string of ankle bells. The left leg is slanting down to the end of the middle line. (I.472)

xxxii (Sivaramamurti, 1970, p. 30)

xxxiii From Shilpa Prakasha Part I

मर्दला

किस्चित् तिर्यक् शिरोदेशः वामरेखान्तरे तथा।

मध्यरेखान्तरे वक्षः वामबाहुर्विचक्षणैः॥५७३

स्कन्धदेशे वामस्कन्धः त्रिभुजबाहुस्पर्शितः।

तदा रम्यस्तथा हस्तः मध्यबाहुसमानतः।

मध्यबाहुः सुरेखायां मर्दलं दिव्यशोभितम्॥४७४

दक्षिणबाहुस्तत्पृष्ठे दक्षिणत्रिभुजावधि।

वामपादांतभागगश्च पादभूमिं समाश्रितः॥४७५

दक्षिणपादस्तत्स्थाने मध्यरेखान्तवर्त्तिनि।

एषा मर्दला परमा उन्मत्ता वादने रम्या॥४७६

The head is slightly bent, touching the left line (of the left triangle). The chest and the left arm are on the middle line. (I.473)

The shoulder part on the left side touches the line of the triangle. Then the beautiful hand is on the horizontal middle line. In the breadth of the middle line is a beautiful mardala (drum) should be carved.

(I.474)

The right arm behind that (mardala) is up to the limit of the right triangle line, the sole of the left foot rests on the ground. (I.475)

The right foot is at the same place along the middle line. This is the divinely beauty of Mardala, intoxicated with her play. (I.476)

With both the hands (beating the drum on both sides) she gives joy by her rhythms.

These are the sixteen maidens that dwell in a temple decorated with sculptures. (I.477)

Surabhi Sharman is presently working as an independent researcher and freelance writer. She has a postgraduate degree in History of Art from National Museum Institute, New Delhi, and a postgraduate degree in Art and Cultural Management from King's College, London. She has an undergraduate degree in History from Lady Shri Ram College, New Delhi. She is interested in history, heritage, art, and culture policies. 